\title{
Effects of Household Waste Generation, Disposal and Management on Farmers' Health in Owerri Metropolis of IMO State, Nigeria
}

\author{
Nwachukwu D.O ${ }^{1}$, Nwelue K.N.K², Ibekwe C.C ${ }^{3}$, Anyanwu U.G ${ }^{4}$, Obilor F5, \\ Ekwe-Emeagha $\mathrm{E}^{6}$,Okereke-Ejiogu, $\mathrm{N}^{7}$, Ellah G.O ${ }^{8}$, Ohajianya D.O ${ }^{9}$
}

\author{
${ }^{1}$ Mezzanine Consulting Associates Ltd, No. 2 Sola Oguntade close Lekki 1, Lagos \\ ${ }^{2}$ Niger Delta Development Commission, Bayelsa State Office, Yenagoa \\ ${ }^{3,4,9}$ Department of Agricultural Economics, Federal University of Technology, Owerri, Imo State. \\ ${ }^{5}$ First Bank of Nig. Ltd, Douglas Road Owerri, Imo State
}

${ }^{6}$ Department of Entrepreneurship, School of General Studies, Alvan Ikoku Federal College of Education Owerri, Imo State

${ }^{7}$ Department of Agricultural Extension, Federal University of Technology Owerri, Imo State

${ }^{8}$ Department of Agricultural Technology, Captain Elechi Amadi Polytechnic Rumuola, Port Harcourt, Rivers State.

\begin{abstract}
The study investigated the effects of household waste generation, disposal and management on farmers health in Owerri metropolis. It specifically ascertained the socio-economic characteristics of the farmers, identified the types and sources of waste in the study area, examined the waste disposal and management methods in the study area examined the effects of inappropriate waste disposal and ascertained the appropriate waste disposal methods used in the study area. A multi stage sampling technique was used to select one hundred and eight farmers from the three Local Government Area in Owerri metropolis. Data were collected using a validated questionnaire and were analyzed using descriptive statistics tool such as mean, frequency, percentage, and mean scores. Results show that waste is majorly generated from markets and residential homes. Waste disposal methods were mainly burning, landfills and open dumping. Its effects includes destroys the beauty of the environment, blocks gutters and drainage system, pollutes the environment among others. Subsequently, appropriate waste disposal methods in the study area includes burning of waste (29.17\%), placing of bins at appropriate places (16.07\%). The study recommends amongst others that waste management environmental agency should make waste dumps or receptacles accessible to residents, public campaigns should be embarked upon to educate the citizens on ills of dirty environment.
\end{abstract}

Keywords- Farmers' health, household waste generation, waste disposal, waste management.
Contribution to knowledge: This study is one of the few studies that evaluated effects of waste generation disposal and management on farmers' health. It also found that wastes are majorly generated from markets and residential homes, and disposed through burning, landfills and open dumping, which destroys beauty of the environment, blocks drainages and pollutes the environment.

\section{INTRODUCTION}

The day to day activities of man generally draw inputs from the natural base in his environment. This may be by way of raw materials for industrial production or by direct utilization of the resources from the reserve in land, water and air. However, the use of these resources in turn results in the generation of various classes of unwanted, useless, damaged and discarded materials termed "waste" (Anurigwo, 2000). Waste is defined as any useless, unwanted and discarded material that is no longer needed and therefore must be thrown away (Ruchi and Avinash (2007). Waste therefore, is any unavoidable material resulting from industrial, household, and/or commercial activity for which there is no economic demand by the owner and which must be disposed of (Ofodile, 2002).

In every human activity, waste is generated and man continues to generate waste all his life. Waste generation is unavoidable by-product of many aspects and types of human activities and households. Household wastes are those unwanted materials (which must be discarded), produced in the kitchens or by any other activities of households or homes (Attah, 2003). They include food and packaging materials, leathers, metals, bottles (glasses), 
plastics, polythene (sachet water and polythene bags), clothes, papers, ceramics, and vegetables/leaves and construction materials among others (Egun, 2012). Waste generation is a common feature in urban and rural households. With annually generated solid waste in Nigeria been more than 25 million tonnes of $0.66 \mathrm{~kg} / \mathrm{cap} / \mathrm{day}$ in urban areas and $0.44 \mathrm{~kg} / \mathrm{cap} /$ day in rural areas (Adeniran, (2005) and Babatunde et al., 2013). Population pressure on the available living areas, people's poor attitude to waste disposal, the shift from agriculture to manufacturing, resulting in the use of more plastics, glasses, metals, polythene and others, is an indication that we are certainly heading to a crises stage if unmanaged and as such make waste disposal practices an important topic of discourse if man has to live in harmony with his environment.

One of the challenging environmental problem facing urban centers worldwide, particularly in developing countries is the improper management of municipal solid waste (APO, 2007). Solid waste comes from residential, institutional, commercial, agricultural or even industrial discards while municipal solid waste has emerged as one of greatest generated hazards (Benjamin, Emmanuel \& Gideon, 2014; ABUJA-CITISERVE, 2004). The Management of municipal solid waste consist of practices involving waste generation, collection, sorting, storage, transport, transfer, processing and disposal (Habib, Abdolhossinpari \& Hamed, 2014), which can lead to environmental pollution like land degradation, vector breeding ground, offensive odours, emissions of toxic gases and groundwater contamination if not managed effectively in urban areas as noted by Farasat et al., (2015) and even the formation of leachates which contains heavy metals, microorganisms and radioactive elements (Egharevba, Amengialue, Edobor \& Omoigberale, 2013) especially in dumped open landfills (Olusegun, 2013). Thus municipal waste disposal as reported by Iyanda, Titilope \& Olaniyi (2014) have reached a crucial point in major towns and cities in Nigeria including Owerri urban.

Again, differences in the wealth of communities and countries degree of urbanization and industrialization, and intensity of agricultural activities account for the significant differences in waste treatment and disposal problems faced by developed and developing countries, and between urban and rural areas. In Nigeria, 25million metric tonnes of solid wastes are generated yearly (Ogwueleka, 2009). About 2.2 million people in developing countries die yearly from diseases associated with lack of safe drinking water, lack of adequate sanitation and poor hygiene (Haryanto, and Sutomo, 2012). Expired materials that have no useful value or materials that have outlived their life spans, unwanted substances, scraps that await disposal or recycling, remain a source of environmental degradation and threat to public health in cities worldwide (Faccio et al., 2011). Again, Sanitation deficiency causes environmental and health threats in developing countries. Managing sanitation properly contributes to reducing mortality from diarrhea diseases by $65 \%$ and morbidity by $26 \%$ ( Haryanto, and Sutomo, 2012). All this is as a result of inappropriate waste disposal practices. Waste are dumped into the drainages that block the free flow of runoff water and this practice gives rise to flooding and the communities are adversely affected, some people dumped their waste to the road side, thereby reducing the width of the road and aesthetics of the cities especially in Nigeria. This is evident as one walk across the nook and the crannies of Nigeria; you find heaps of refuse littering the entire landscape, road sides, parks, gardens, commercial centres and other land use (Danbuzu, 2011, Imam et al, 2007). Little attention is given to waste management practices as it is common to see heaps of waste in the major cities littering the streets, dumped indiscriminately in drainages, vacant plots and open space especially in the developing world. This has contributed not only to the spread of communicable diseases in the affected areas; it has effect on flooding and other environmental problems (Wilson et al, 2009; Babalola et al, 2010). Health issues related to waste are complex and gives rise to numerous debates (Department for Environment, Food and Rural Affairs 2004). Given the diversity of pollutants present, management methods and routes of exposure, knowledge remains imperfect and still need to be improved. The uncollected or illegally dumped wastes constitute a starting point for disaster of human health and the environmental degradation. Apart from the increasing quantities, the waste composition and characterization evolves, incomes and changing consumption habits have also been affected by globalization (EPA, 2011). Knowledge of the type and sources of solid waste, method of waste disposal, its effect on farmers' health along with data on the composition of waste generation is basis to the design and operation of the functional element associated with the management of solid waste.

\section{METHODOLOGY}

The study was conducted in Owerri, Imo state. Owerri is the capital of Imo State in Nigeria. Owerri consists of three Local Government Areas including Owerri Municipal, Owerri North and Owerri West. It has an estimated population of about 401,873 as of 2006 (Federal Republic of Nigeria Official Gazette, 2007) and is approximately 100 square kilometres (40 sq mi) in area. Owerri is bordered by 
the Otamiri River to the east and the Nworie River to the south. Its coordinate consists of $5^{\circ} 29^{\prime} 06^{\prime \prime} \mathrm{N}$ $7^{\circ} 02^{\prime} 06^{\prime \prime} \mathrm{E} / 5.485^{\circ} \mathrm{N} 7.035^{\circ} \mathrm{E}$. Owerri has a tropical wet climate according to the Köppen-Geiger system. Rain falls for most months of the year with a brief dry season. The Harmattan affects the city in the early periods of the dry season and it is noticeably less pronounced than in other cities in Nigeria. The average temperature is $26.4{ }^{\circ} \mathrm{C}$. Owerri sits in the rain forest and produces many agricultural products, such as yams, cassava, taro, corn, rubber and palm products. Owerri also sits on huge crude oil and natural gas reserves like most of the Igbo land areas. Important educational institutions in Owerri include Imo State University, Federal University of Technology Owerri, Imo State Polytechnic Umuagwo, Federal Polytechnic, Nekede, African Institute of Science and Technology (AIST CCE Owerri), and Federal College of Land Resources Oforola.

Multi stage sampling technique was used to select the respondents. At the first stage, the three local government areas were purposively selected viz-a-viz Owerri West, Owerri North and Owerri municipal. At the second stage, six (6) communities were randomly selected from Owerri West and Owerri North, which includes; Obinze, Ihiagwa, Nekede, Uratta, Emekuku, and Nazi. In the case of Owerri Municipal no community was selected at this stage because of the fact that their settlements are not known as communities but as villages and residential areas. There are five villages, which include, Umuororonjo, Amawom, Umuonyeche, Umuodu and Umuoyima and the residential areas include, Ikenegbu, Aladinma, World bank housing estate etc. At the third stage, 2 villages were randomly selected from the communities selected from Owerri West and Owerri North namely; Umueje, Umuanunu, Umuelem, Nakaramoche, Umudibia, Umualum, Ezeogba, Ezedibia, Akwakuma, Amakohia, Umuakali, and Umuezuo, while the five (5) villages and one residential area was selected from Owerri Municipal. At the final stage, 6 farmers were randomly selected from the villages making it a total number of one hundred and eight (108) respondents. Structured questionnaire was used to collect primary data from the field. Data analysis was achieved using descriptive statistics like mean, frequency, and percentage.

\section{RESULTS AND DISCUSSION}

3.1 Socio-economic Characteristics of farmers.

The socioeconomic features of the farmers are presented in table 1.

Table.1: Distribution offarmers according to their Socioeconomic Characteristics

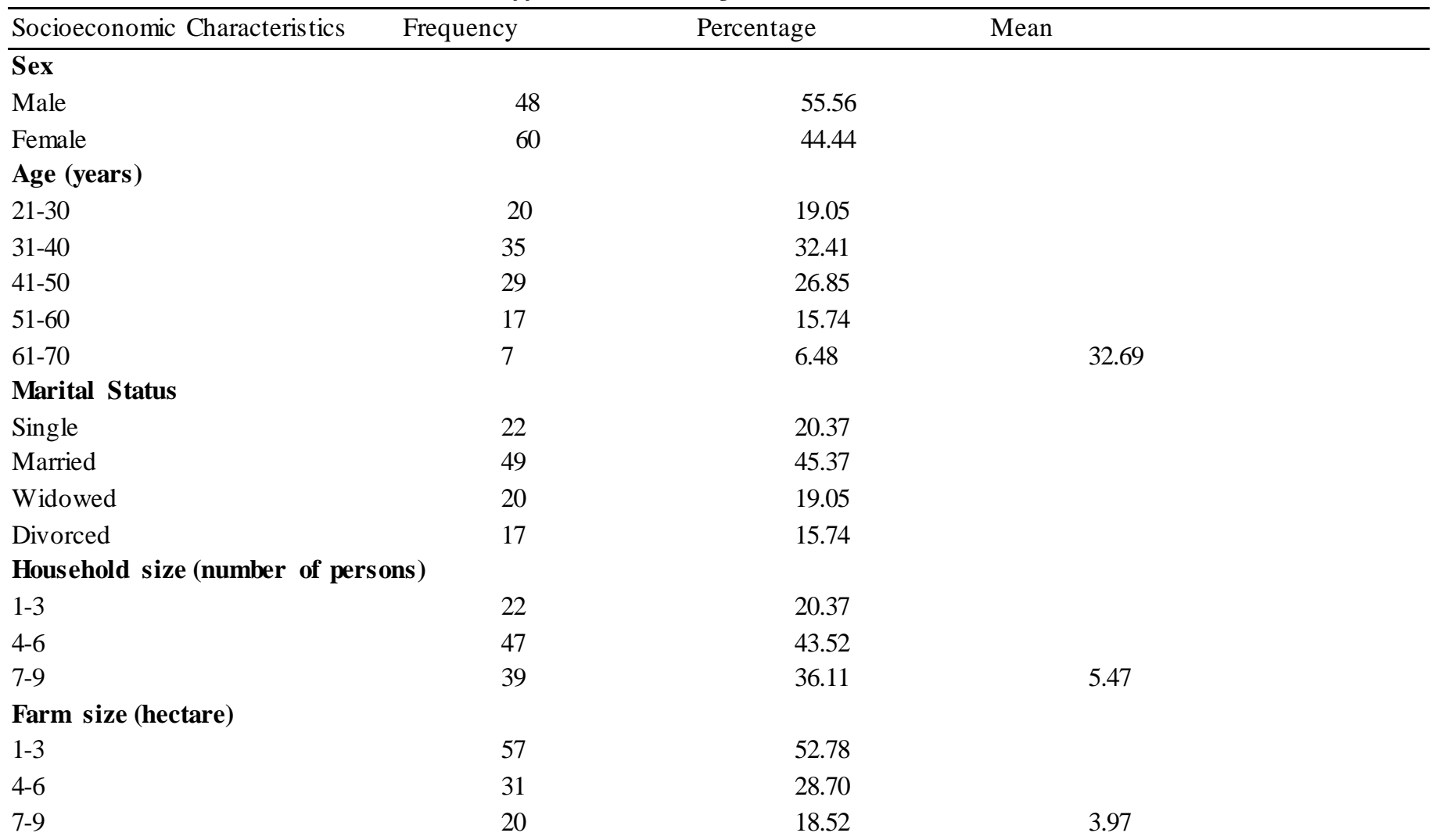


Farming experience (years)

\begin{tabular}{|c|c|c|c|}
\hline $11-20$ & 17 & 15.74 & \\
\hline $21-30$ & 22 & 20.37 & \\
\hline $31-40$ & 40 & 37.04 & \\
\hline $41-50$ & 17 & 15.74 & \\
\hline $51-60$ & 12 & 11.11 & 34.11 \\
\hline \multicolumn{4}{|l|}{ Education level (years) } \\
\hline 0 (No formal education) & 26 & 24.07 & \\
\hline $1-6$ & 42 & 38.89 & \\
\hline $7-12$ & 30 & 27.78 & \\
\hline $13-18$ & 10 & 9.26 & 9.2 \\
\hline \multicolumn{4}{|l|}{ Income (naira) } \\
\hline $11000-20000$ & 26 & 24.07 & \\
\hline $21000-30000$ & 43 & 39.81 & \\
\hline $31000-40000$ & 21 & 19.44 & \\
\hline $41000-50000$ & 7 & 6.48 & \\
\hline $51000-60000$ & 11 & 10.19 & 29388.89 \\
\hline \multicolumn{4}{|c|}{ Social organization membership } \\
\hline Yes & 51 & 47.22 & \\
\hline No & 57 & 52.78 & \\
\hline \multicolumn{4}{|l|}{ Extension visits } \\
\hline Yes & 52 & 48.15 & \\
\hline No & 56 & 51.85 & \\
\hline \multicolumn{4}{|c|}{ Number of times visited by extension agents } \\
\hline Weekly & 11 & 21.15 & \\
\hline Forth nightly & 14 & 26.93 & \\
\hline Monthly & 27 & 51.92 & \\
\hline
\end{tabular}

Source: Field Data, 2017.

The result in table 1 . showed that $55.56 \%$ of the farmers were female while $44.44 \%$ of them were male. This implies that majority $(44.44 \%)$ of waste managers at household level are female. It has been hypothesized that women demonstrate great enthusiasm about environmental issues than men (Hampel et al, 1996). The mean Age of the farmers' was 32.69 years which indicates that the Farming population of the study area is quite young and active in Farming. This further strengthens the findings of Bamiro, Otunaiya and Idowu (2012) who said that most active group among rural farmers' falls within 30-50 years of age. It was found that $45.37 \%$ of the farmers were married, $20.37 \%$ of them were single, $19.05 \%$ of them were Widowed while $15.74 \%$ of the farmers were Divorced. This supports the finding of Sanful and Darko (2010), who stated that the majority of the farmers $(74.5 \%)$ are faced with responsibilities of taking care of their family. The result also revealed that $43.52 \%$ of the farmers in the study area had an approximate average household size of 6 persons indicating that the farmer's household contributes greatly to Farm labour. This agrees with Baruwa and Oke 2012 who stated that the size of household is a good indicator of labour available for farm work. The mean Farm size was 3.97 ha which implies that farmers in the study area are small holder farmers operating small farm holdings. This supports the study of Ekong (2005) who stated that small holders farmers still persist in Nigeria based on Inheritance and prone to fragmentation. Average Farming experience was 34.11 years indicating that with more experience, a farmer can become less averse to the risk implied by adopting a new technology (Nwaobiala, 2014). It was further observed that $38.89 \%$ of the respondents spent $1-6$ years in school, $27.78 \%$ of them spent $7-12$ years in school, $24.07 \%$ of them had no formal education, while only 9.26 of them had Tertiary education and spent 13-18 years in school with mean level of education of 9.2years, indicating that the farming population in the study area is quite literate and have acquired one form of education or the other. This further support the statement by Obinne (1991), who stated that education is advantageous to farmers as it will lead to increased adoption of innovation. The mean income is N29, 388.89. According to Adedibu and Okekunle (1990) 
personal income influences waste generation due to its impact on individual consumption pattern. In addition, the rate of solid waste generation per capital increase as the standards of living improves (UNCHS, 1992). It revealed that $52.78 \%$ of the respondents do not belong to social organisation, while $47.22 \%$ of them belong to one social organisation or the other. The result further revealed that $51.85 \%$ of farmers in the study area were not visited by extension agents while $48.15 \%$ of them were visited. This shows that Extension contact in the study area is relatively poor. Though a good number of farmers were visited. It is hypothesized that contact with extension workers and adequate information on production techniques will increase farmer's likelihood of adoption of improved agricultural practices (Salau et al., 2014). Majority $(51.92 \%)$ of the farmers visited by the extension agents were visited on a monthly basis, $26.93 \%$ of them were visited on a forth nightly basis, while, $21.15 \%$ of them were visited weekly.

\subsection{Types and Sources of waste Generated by} Hous eholds.

The distribution of the types and sources of waste generated by households in the study area is presented in tables 2 . and 3. respectively.

Table.2: Distribution offarmers according to Types of Waste

\begin{tabular}{lcc}
\hline Types of waste & Frequency & Percentage (\%) \\
\hline Biodegradable & 51 & 47.22 \\
Non-biodegradable & 57 & 52.78 \\
Total & 108 & 100 \\
\hline
\end{tabular}

Source: Field Data, 2017.

Table 2. shows the distribution of farmers according to type of waste generated in the study area. The result indicates that $52.78 \%$ of the farmers said the waste generated in the study area were Non-biodegradable waste while $47.22 \%$ of them said it was Biodegradable waste. This is an implication that both biodegradable and non-biodegradable wastes are present in the study area. The economic and social status of the city could be the reason for the greater percentage $(52.78 \%)$ of non-biodegradable wastes generated in the area. This finding disagrees with earlier work by Oil Resources and Allied Investment Limited (2008) which gave the figures of biodegradable and nonbiodegradable wastes as $54 \%$ and $46 \%$ respectively.

Table.3: Distribution of Farmers according to Sources of Waste

\begin{tabular}{|c|c|c|}
\hline Sources of waste & Frequency** & Percentage (\%) \\
\hline Residential homes & 72 & 23.92 \\
\hline Markets & 101 & 33.55 \\
\hline Hospitals & 48 & 15.95 \\
\hline Farms & 43 & 14.29 \\
\hline Business places & 37 & 12.29 \\
\hline
\end{tabular}

**Multiple responses recorded

Source: Field survey data, 2017.

Investigation into the major sources of solid waste generation presented markets (33. 55\%) and residential homes $(23.92 \%)$ as the main sources of waste in the study area as seen in table 3. The table also indicates that $15.95 \%$ were generated from hospital, $14.29 \%$ of them generated from Farms, while $12.29 \%$ of them were generated in business places. It is certain that markets are centre's of commercial activities in any city and accommodate greater number of people than any other sector at any given time. The increased human population and activities in both markets and residential homes could account for the huge quantities of different kinds of wastes around the municipality and its environs. This finding concurs with the view of Ogwueleka (2009) who found that markets and residential homes are the major sources of wastes.

\subsection{Methods of waste disposal and management}

The methods of waste disposal and management in the study area are presented in Table 4. 


\begin{tabular}{lll}
\hline Waste disposal methods & Frequency $* *$ & Percentage $(\%)$ \\
\hline Landfills & 102 & 26.91 \\
Burning & 106 & 27.97 \\
Open dumping & 98 & 25.86 \\
Ocean dumping & 42 & 11.08 \\
Grinding and discharge in sewers & 31 & 8.17 \\
Waste management & & \\
Recycling & 47 & 27.48 \\
Incineration & 52 & 31.52 \\
Composting of waste & 37 & 22.42 \\
Plasma gasification & 0 & 0 \\
Waste to energy & 10 & 6.06 \\
Waste minimization & 15 & 9.09 \\
Ploughing in Field & 4 & 2.42 \\
\end{tabular}

** Multiple responses recorded

Source: Field Data, 2017

Table 4 showed that $26.91 \%$ of the farmers dispose waste through landfills, $27.97 \%$ through Burning, $25.86 \%$ of them through open dumping, $11.08 \%$ of them through Ocean dumping or dumping in river bodies and flowing/running water. It further shows that $31.52 \%$ of farmers carry out Incineration as management practices of waste, $27.48 \%$ do Recycling, $22.42 \%$ compost waste, $9.09 \%$ do waste minimization, $6.06 \%$ convert waste to energy which $2.42 \%$ of them plough the waste in the field especially as a result of mechanized Farming. The result implies that farmers adopt different methods of waste disposal and uses several strategies to manage waste the best way possible to them in the study area. The reasons for adopting open dumping as the main waste management method could be unavailability of adequate man-power and equipment, inaccessibility to final dumpsites, people's poor attitude towards

environmental sanitation as well as the method being cheap but not cost effective. This finding agree with those of Olafusi (2004) and Iman et al., (2007) who reported that in most cities of Nigeria and other developing countries, the greater percentages of waste generated are dumped on the surface of the ground along major roads, streets and open spaces. The finding was further confirmed by the information obtained from field trips and direct observations which revealed the existence of more than 250 dumpsites of different sizes within the municipality and its environs.

\section{4: Effect of Inappropriate Waste disposal on Farmers' Health}

The effect of inappropriate waste disposal on farmers' health is presented in table 5.

Table.5: Distribution offarmers according to effects of inappropriate waste disposal

\begin{tabular}{lll}
\hline Effects & Mean & Standard deviation \\
\hline Foul odour & 4.204 & 0.992 \\
Disease outbreak & 4.370 & 0.718 \\
Attract animals like rats & 4.037 & 1.013 \\
Pollutes the environment & 4.426 & 0.726 \\
Blocks gutters and drainage system & 4.444 & 0.777 \\
Destroys the beauty of the & \\
environment & 4.602 & 0.528 \\
Disrupts free movement to and from & & \\
the farm & 4.129 & 1.014 \\
Soil infertility & & \\
Farm flooding & 4.306 & 1.008 \\
& 4.1481 & 1.151 \\
\hline
\end{tabular}

Mean <3.0: Not accepted; Mean $\geq 3.0$ : Accepted

Source: Field Data, 2017. 
The result in Table 5 showed that all the effects listed are observed as effects in the study area, however some effects are ranked higher because of its prevalence in the study area. As observed effects such as destroys the beauty of the environment $(M=4.602)$, Blocks gutters and drainage system $(M=4.444)$, Pollutes the environment $(M=4.426)$, disease outbreak ( $M=4.370)$, soil infertility $(M=4.306)$ are major effects as seen in the study area. The result therefore revealed that Owerri metropolis is associated with poor looking environment as a result of inappropriate waste disposal. The standard deviations for all the items were low indicating high concentration around the mean and this could have implication on the farmer's heath. This agrees with the study by Madukwe et al., (1996) that the heap of the dump site creates obnoxious odour and encourage the growth of pathogens and insect pests lay their eggs on the heap.

\subsection{Appropriate Waste Disposal Methods}

The appropriate waste disposal methods identified in the study area is presented in table 6 .

Table.6: Distribution offarmers according to appropriate waste disposal methods in the study area.

\begin{tabular}{lll}
\hline Methods & Frequency** & Percentage (\%) \\
\hline Placing bins at designated places & 54 & 16.07 \\
Burning of waste & 98 & 29.17 \\
$\begin{array}{l}\text { Recycling of waste } \\
\text { Composting of waste }\end{array}$ & 32 & 9.53 \\
$\begin{array}{l}\text { Residents should be educated on } \\
\text { appropriate waste disposal }\end{array}$ & 47 & 11.01 \\
$\begin{array}{l}\text { Separate bins for decomposable and } \\
\text { non-decomposable waste }\end{array}$ & & 14.28 \\
$\begin{array}{l}\text { Educating households } \\
\text { appropriate waste disposal methods }\end{array}$ & 20 & \\
& 1 & 5.95 \\
\end{tabular}

**Multiple responses recorded.

Source: Field Data, 2017

Table 6 showed that $29.17 \%$ of the farmers exercise opening burning of waste, $16.07 \%$ uses bins placed in appropriate places, $14.28 \%$ of them reveal that Residents should be educated on appropriate waste disposal, $13.98 \%$ also reveal that households should be educated on appropriate waste disposal, $11.01 \%$ compost waste while $9.53 \%$ recycle waste, only $5.95 \%$ suggested the use of separate bins for decomposable and non-decomposable waste. This implies that there are several appropriate measures available in the study area that household could adopt for proper waste disposal to reduce waste effect on farmers. The present finding is in consonance with the study of Ugboaja (2002) who reported that a greater percentage of the residents did not sort waste into biodegradable and nondegradable. This accounts for large volume of waste deposited at the central positions in the municipal council. The finding is also in line with that of Chukwu (2012) who reported that many cities in Nigeria today are suffering from sudden increase in solid waste and poor disposal practice.

\section{CONCLUSION AND RECOMMENDATION}

From the findings it was observed that due to rapid urbanization in Owerri metropolis with its numerous hotels, fast food centers and markets the volume of waste generated is on the increase and has become a major concern for farm households and the government at large. Inappropriate waste disposal practices have resulted in environmental degradation with serious health implications on farmers. Households should conceive appropriate waste disposal practices as a crusade against poor living environment. It is implicit that Owerri metropolis spends huge sums of money in waste management. Therefore its residents need to be educated on efficient waste disposal practices to reduce health hazard on farmers., waste management environmental agency should make waste dumps or receptacles accessible to residents and appropriate sorting of waste into decomposable and non-decomposable components should be practiced by the residents. 


\section{REFERENCES}

[1] ABUJA CITISERVE, (2004). Estimates of Waste Generation Volumes and Income Potential in Abuja, SLGP Consultants' Report Number 805 (Original Number 174) DFID CNTR: 000512A, Department for International development.

[2] Adedibu, A.A. and Okekunle,A.A. (1989). Issues in the environmental sanitation of Lagos mainland, Nigeria. International Journal of Environmental Studies. 9(2): 91-100.

[3] Adeniran .K.A, (2005) Assessment of solid waste management in Ilorin metropolis, Kara state, Nigeria USEP, Journal of research information in civil Engineering, Vol 2. No. 1.

[4] Anurigwo, S. (2000). "Environmental sanitation and municipal waste management in Imo State: the way forward" paper presented at the workshop on environmental sanitation and proper waste management in Imo state organized by ISEPA and PATEB environmental company 2nd November.

[5] Asian Productivity Organization (APO). (2007). Solid waste management: issues and challenges in Asia. Asian Productivity Organization, Tokyo. Edited by the Environmental management centre Mumbai, India. ISBN 92-833-7058-9.

[6] Attah (2003). Effects of air pollution arising from associated gas flaring on the economic life of the people of oil producing communities in nigeria. ISBN 0970-2083.

[7] Babalola, A., Ishaku, H.T., Busu, I. and Rafee, M.M. (2010): The Practice and Challenges of Solid Waste Management in Damaturu, Yobe State.

[8] Babatunde .B.B, Vincent .A.I.F, Woke G.N, Atarhinyo .E, Aharanwa .U.C, Green .A.F, Isaac J.O, (2013) Comparative analysis of municipal solid waste (MSW) composition in three local government areas in Rivers State, Nigeria, African Journal of Environmental Science and Technology874-881 Vol 7(9).

[9] Bamiro, O. M., Otunaiya, A. O. and Idowu, A. O. 2012. Economics of horizontal integration in Poultry industry in South West Nigeria. International Journal of Poultry Science 11(1): Pp39-46 2012.

[10] Baruwa, O. J. and Oke, J. T. O. (2012). Analysis of the technical efficiency of small-holder Cocoyam Farms in Ondo State, Nigeria. Tropicultura, 30(1):36-40.

[11] Benjamin T.A., Emmanuel, E. O. \& Gideon, A.D. (2014). Characterization of Municipal Solid Waste in the Federal Capital Abuja, Nigeria. Global Journal of Science Frontier Research: H Environment \& Earth Science. Vol. 14, Issue 2, Version 1.0.
[12] Bruce, J.H. (1998): Sustainable Development: The Essential Element, Waste Management 4. 32-38.

[13] Chukwu, A. O. (2012). The effect of indiscriminate disposal of plastic waste in the environment: A case study of Enugu. An unpublished degree dissertation BURP department of urban and regional planning. Universityof Nigeria, Enugu campus.

[14] Danbuzu, S.A.L. (2011). Composition and Spatial Distribution of Solid Waste Collection Point in Urban Katsina, Northern Nigeria. An M.sc Land Resource (Development). Research proposal submitted to the Department of Geography. B. U. K

[15] Department for Environment, Food and Rural Affairs. (2004) "Review of Environmental and Health Effects of Waste Management: Municipal Solid Waste and Similar Wastes," Queen's Printer and Controller of HMSO

http://archive.defra.gov.uk/environment/waste/statistic s/documents/health-summary.pdf

[16] Egharevba, A.P., Amengialue, O.O., Edobor, O., Omoigberale, M.N.O. (2013) Microbiological and PhysicoChemical Quality Assessment of Solid Waste Dumpsites in Benin City, Nigeria, International Journal of Agriculture and Biosciences, 2(6): 344-348.

[17] Egun N. (2012). The waste to wealth concept: waste market operation in delta State Nigeria. Greener Journal of Social Science Research.

[18] Ekong, E.E. (2005). An introduction to rural sociology. Second edition. Dove education publishers, Uyo Nigeria, Pp 341-351.

[19] Environmental Protection Agency (EPA) (2011). Recommended use of body weight $3 / 4$ as the default method in derivation of the oral reference dose. Risk Assessment Forum, Washington, DC; EPA/100/R11/0001. Available online at http://www.epa.gov/raf/publications/interspe ciesextrapolation.htm

[20] Faccio, M., A. Persona and G. Zanin, 2011. Waste collection multi objective model with real time traceability data. J. Waste Manage., 31: 2391-2405.

[21] Federal Republic of Nigeria Official Gazette (2007). OFFICIAL GAZATTE (FGP 71/52007/2,500 (OL24) 2007 Page 2

[22] Habib, F., Abdolhossinpari, Z., Hamed, F., Hossein, M., (2014). Municipal solid waste characterization and its assessment for potential compost production: A case study in Zanjan city Iran, American Journal of Agriculture and Forestry. 2(2): 39-44.

[23] Hampel, B., Boldero, J. and Holdsworth, R. (1996). Gender patterns in environmental consciousness 
among adolescents. Austrillian and New Zealand

Journal of Sociology. 32(1), 211-218.

[24] Haryanto, B.; Sutomo, S. (2012). Improving access to adequate water and basic sanitation services in Indonesia. Rev. Environ. Health, 27, 159-162.

[25] Imam, A. Mohammed, B. Wilson, D.C and Cheeseman, C. R (2007). Solid waste management in Abuja. Doi:10.1016/j.wasman. 2007.01.006.

[26] Iyanda, T.A. and Olaniyi, O.A. (2014). Assessment of municipal waste disposal methods. A case study of Ibadan, Nigeria. Vol. 6, No. 12.

[27] Madukwe MC, Okoli EC, Eze SO (1996). Analys is and Comparison of the Agricultural Technology transfer system in Nigeria. African Journal of Agricultural Research. Vol. 26, pp.111- 115.

[28] Nwaobiala, C.U. (2014). Socio-Economic Factors Influencing Farmers' Participation in CommunityBased Programme in Abia and Cross River States of Nigeria. Journal of Agricultural Extension Vol. 18(1) June, 2014 ISSN 1119-944X.

[29] Obinne, C. P. O. (1991). Adoption of improved cassava production technologies by small scale farmers in Bendel, State. J. Agric. SciTechnol, 1(1): $12-15$.

[30] Ofodile, S. E. (2002). "Solid waste management. A case study of Port-Harcourt". A paper presented at the national conference of Nigerian environment society (NES) Rivers State on 6th June.

[31] Ogwueleka, T.C. (2009). Municipal Solid Waste Characteristics and Management in Nigeria. Oil Resources and Allied Limited (2008). The study of Solid Waste Generation and Management in Owerri Metropolitan City. A consultancy service agreement report presented to the Ministry of petroleum and Environment. Owerri: August 13, 2008.

[32] Olafusi, O.R (2004) Waste Disposal and Management. A case for healthy environment.Unpublished Housing Seminar Report, Department of Architecture, federal University of technology, Akure, Nigeria.

[33] Olusegun, O.I. (2013). Geologic And Geotechnical Evaluation Of An Open Landfill For Sanitary Landfill Construction In Ilorin Southwestern Nigeria, Journal of Environment and Earth Science. Vol. 3 No.3

[34] Ruchi k. and Avinash S. (2000). Problems of household waste disposal. Journal of Human Ecology. 21(3): 199-201.

[35] Salau E. S., Lawee A. Y., Luka G. E., \& Bello D. (2014). Adoption of improved fisheries technologies by fish farmers in southern agricultural zone of
Nasarawa State, Nigeria. Journal of Agricultural Extension and Rural Development, 6(11), 339-346.

[36] Ugboaja, C. N. (2002). "Solid waste disposal (Domestic waste) in Port-Harcourt. An unpublished undergraduate research project work to the Department of EVT; FUTO, Owerri.

[37] United Nations Centre for Human Settlements (UNCHS)(1992). Improving the living environment for sustainable future. UNCHS, Nairobi.

[38] Wilson, D.C., Adebisi, O.A, Kaine, C and Cheeseman, C.R. (2009): Building Recycles rates through the Informal Sector. Waste Management. 29(2). 